\title{
1 Disentangling microbial syntrophic mechanisms for hexavalent \\ 2 chromium reduction in autotrophic biosystems
}

3 Baogang Zhang ${ }^{1}$, Jun Liu ${ }^{2,3 *}$, Yizhi Sheng ${ }^{3 *}$, Jiaxin Shi ${ }^{1}$, Hailiang Dong ${ }^{2 *}$

$4{ }^{1}$ School of Water Resources and Environment, Key Laboratory of Groundwater

5 Circulation and Environmental Evolution (China University of Geosciences Beijing),

6 Ministry of Education, Beijing 100083, China

$7 \quad{ }^{2}$ State Key Laboratory of Biogeology and Environmental Geology, China University of

8 Geosciences, Beijing 100083, China

$9{ }^{3}$ Department of Geology and Environmental Earth Science, Miami University, Oxford, $10 \mathrm{OH} 45056$, USA

*Corresponding author

13

14

15

16

17

18

19

20

21 Number of tables: 0

22 Number of figures: 7

23 Number of pages: 13 


\section{Materials and Methods}

\section{Experiments for methane and sulfur metabolisms verification}

Because $\mathrm{CH}_{4}$ was under detection limit in the S-bioreactor, to verify the role of $\mathrm{CH}_{4}$ in the $\mathrm{Cr}(\mathrm{VI})$ bioreduction process in this reactor, an additional S-bioreactor adding 10 $\mathrm{mM}$ 2-bromoethanesulfonate (BES) was employed to inhibit the potential methanogenesis after the steady-state condition. ${ }^{1}$ Additionally, an extra bioreactor with only methane in the headspace but without $\mathrm{S}^{0}$ addition was assigned as a methane-based bioreactor. The rubber plug was first used to seal the methane-based bioreactor, and then the headspace air was expelled $(20 \mathrm{ml})$, after which the methane was injected via a syringe.

To further verify the possible pathways of sulfide generation, additional supplementary experiments were conducted. The S-bioreactor was continued to run one cycle after a typical operating cycle to measure sulfide. In addition, synthetic groundwater containing only $100 \mathrm{mg} / \mathrm{L}$ thiosulfate was re-added to the S-bioreactor to monitor the concentration of sulfide in a typical operating cycle.

\section{Phylogenomic and phylogenetic analyses}

Excluding QR_Bin.4 where the 16 ribosomal proteins were not predicted, the other 22 retrieved genomes and 288 reference genomes available in the Genome Taxonomy Database were applied to construct a phylogenomic tree based on a concatenated alignment of 16 ribosomal proteins as previously suggested. ${ }^{2,3}$ In brief, each of the 16 ribosomal protein sequences was aligned using MAFFT (version 7.3.13), ${ }^{4}$ and then 
trimmed using TrimAL with the parameters "-gt 0.95 -cons 50".5 The curated alignments were concatenated, and a phylogenomic tree was built using IQ-TREE (version 1.6.10) with the parameters "LG+I+G4 -alrt 1000 -bb 1000". ${ }^{6}$ Additionally, phylogenetic analyses were performed for the $\operatorname{ds} A B$ and $\operatorname{mcr} A B G$ genes as mentioned above. The generated treefiles were uploaded to iTOL for visualization and formatting.

\section{References}

(1) Webster, T. M.; Smith, A. L.; Reddy, R. R.; Pinto, A. J.; Hayes, K. F.; Raskin, L. Anaerobic microbial community response to methanogenic inhibitors 2bromoethanesulfonate and propynoic acid. Microbiologyopen 2016, 5, 537-550.

(2) Hug, L. A.; Baker, B. J.; Anantharaman, K.; Brown, C. T.; Probst, A. J.; Castelle, C. J.; Butterfield, C. N.; Hernsdorf, A. W.; Amano, Y.; Ise, K.; Suzuki, Y.; Dudek, N.; Relman, D. A.; Finstad, K. M.; Amundson, R.; Thomas, B. C.; Banfield, J. F. A new view of the tree of life. Nat. Microbiol. 2016, 1, 16048.

(3) Tan, S.; Liu, J.; Fang, Y.; Hedlund, B. P.; Lian, Z. H.; Huang, L. Y.; Li, J. T.; Huang, L. N.; Li, W. J.; Jiang, H. C.; Dong, H. L.; Shu, W. S. Insights into ecological role of a new deltaproteobacterial order Candidatus Acidulodesulfobacterales by metagenomics and metatranscriptomics. ISME J. 2019, 13, 2044-2057.

(4) Katoh, K.; Asimenos, G.; Toh, H. Multiple alignment of DNA sequences with MAFFT. Methods Mol. Biol. 2009, 537, 39-64.

(5) Capella-Gutierrez, S.; Silla-Martinez, J. M.; Gabaldon, T. trimAl: a tool for 
68 automated alignment trimming in large-scale phylogenetic analyses.

69 Bioinformatics 2009, 25, 1972-1973.

70 (6) Nguyen, L. T.; Schmidt, H. A.; von Haeseler, A.; Minh, B. Q. IQ-TREE: A fast

71 and effective stochastic algorithm for estimating maximum-likelihood

72 phylogenies. Mol. Biol. Evol. 2015, 32, 268-274.

73 


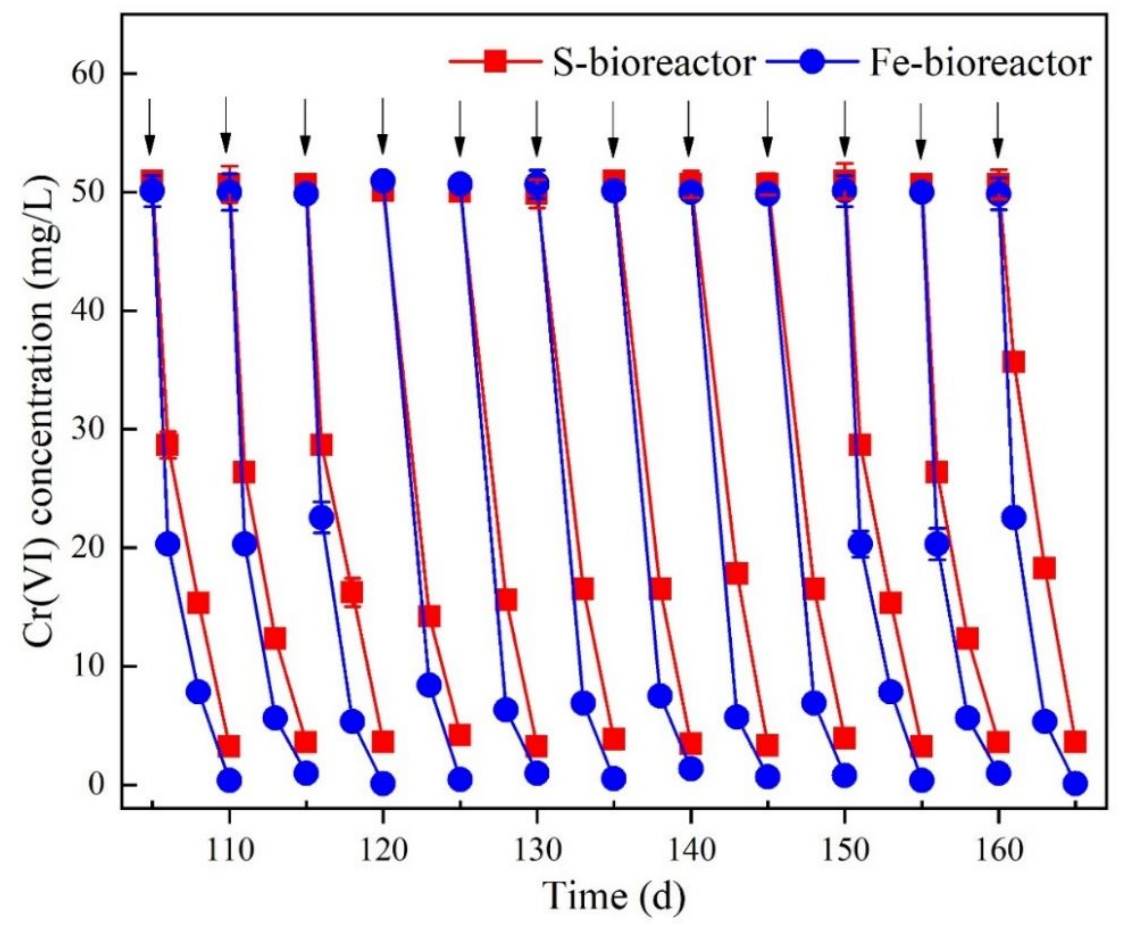

74

Figure S1. Time-course operations of $\mathrm{Cr}(\mathrm{VI})$ reduction in S- and Fe- bioreactors.

Multiple cycles of $\mathrm{Cr}(\mathrm{VI})$ measurements were conducted. 

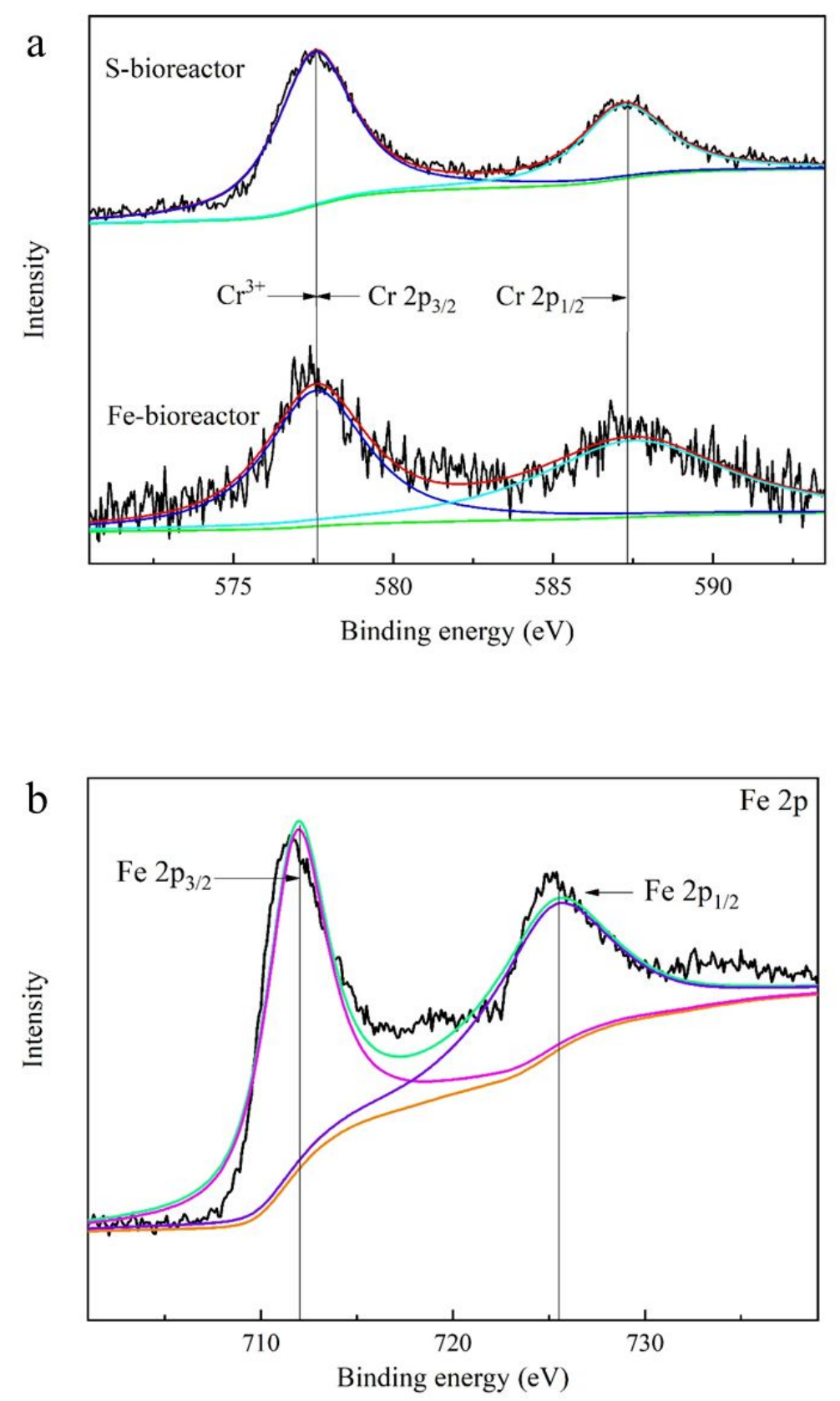

78 Figure S2. XPS spectra of $\mathrm{Cr} 2 \mathrm{p}$ for the generated precipitates in S- and Fe- bioreactors (a), and Fe 2p XPS spectra for precipitates in the Fe-bioreactor (b). In panel a, the dark blue and light blue curves represent the peaks of $\mathrm{Cr} 2 \mathrm{p} 3 / 2$ and $\mathrm{Cr} 2 \mathrm{p} 1 / 2$, respectively,

81 and the green curve is the baseline. In panel $b$, the pink and purple curves represent the 82 peaks of $\mathrm{Fe} 2 \mathrm{p} 3 / 2$ and $\mathrm{Fe} 2 \mathrm{p} 1 / 2$, respectively, and the orange curve is the baseline. All curves were fitted by XPS Peak Fit software. 


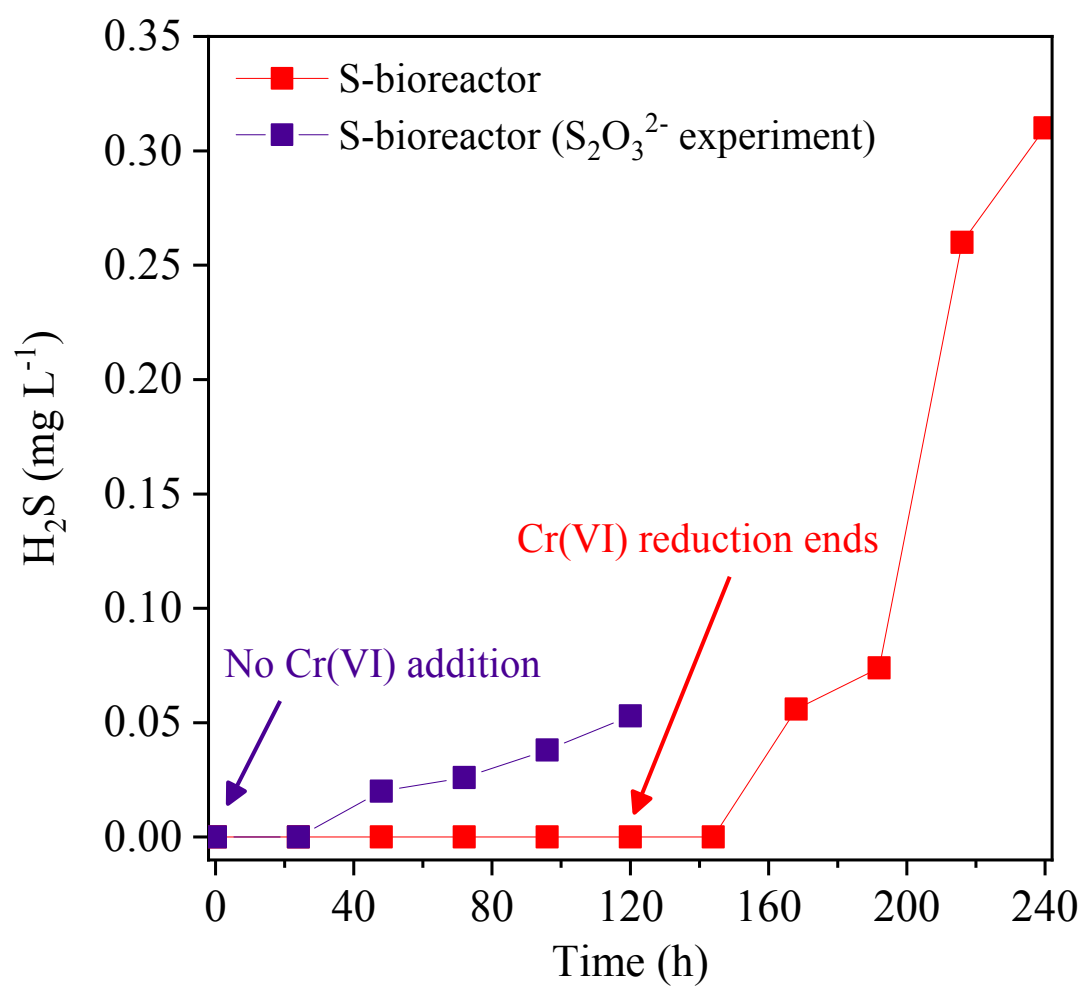

85 Figure S3. Change of $\mathrm{H}_{2} \mathrm{~S}$ concentrations in the S-bioreactor and another S-bioreactor with addition of thiosulfate $\left(\mathrm{S}_{2} \mathrm{O}_{3}{ }^{2-}\right)$ but without addition of $\mathrm{Cr}(\mathrm{VI})$. The S-bioreactor

87 was continued to run one cycle after a typical operating cycle to investigate sulfide 88 production. The sulfide concentration was detected on the 7-day and increased with 89 time (red color line). The highest sulfide concentration of $0.31 \mathrm{mg} / \mathrm{L}$ was detected on 90 the 10-day. Synthetic groundwater containing only $100 \mathrm{mg} / \mathrm{L}$ thiosulfate was re-added to another S-bioreactor to monitor the concentration of sulfide in a typical operating

92 cycle (purple color line). The sulfide concentration accumulated gradually and reaching 93 the highest $0.053 \mathrm{mg} / \mathrm{L}$ at the end of the cycle. 

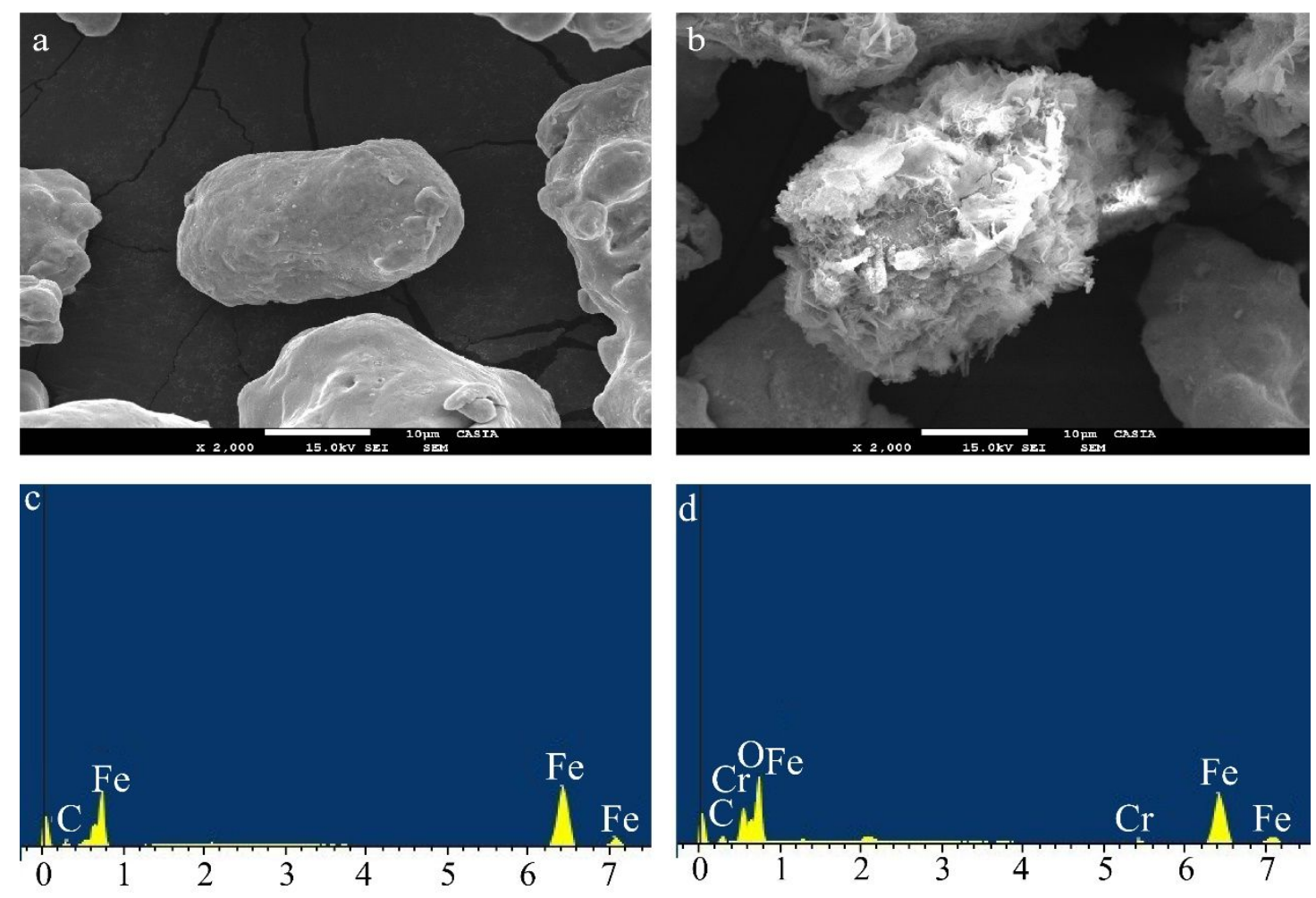

97 Figure S4. SEM images and corresponding EDS patterns of solid $\mathrm{Fe}^{0}$ before and after

98 use. (a) SEM image of initial state $\mathrm{Fe}^{0}$; (b) SEM image of $\mathrm{Fe}^{0}$ after one operating cycle;

99 (c) EDS pattern of initial state $\mathrm{Fe}^{0}$; (d) EDS pattern of $\mathrm{Fe}^{0}$ after one operating cycle. 

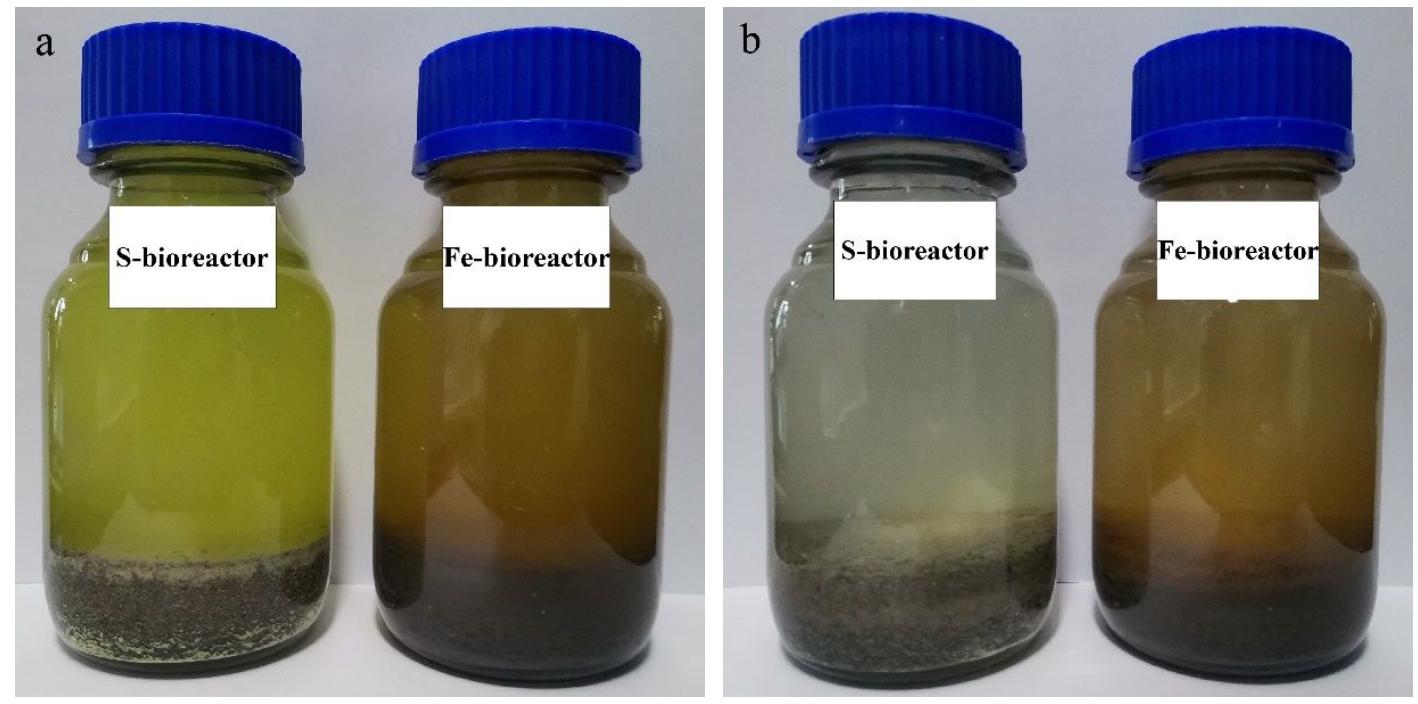

Figure S5. Photographs of the mineral generated in bioreactors during operation. (a)

103 Before the reaction. (b) After the reaction. 
a

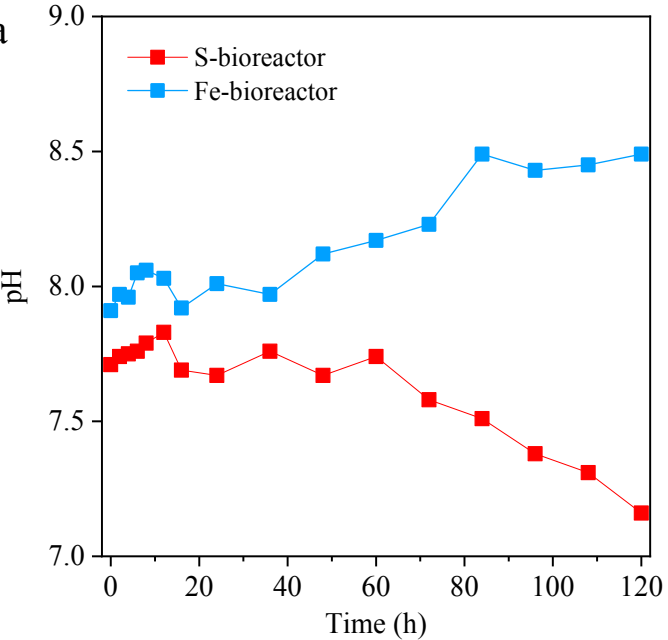

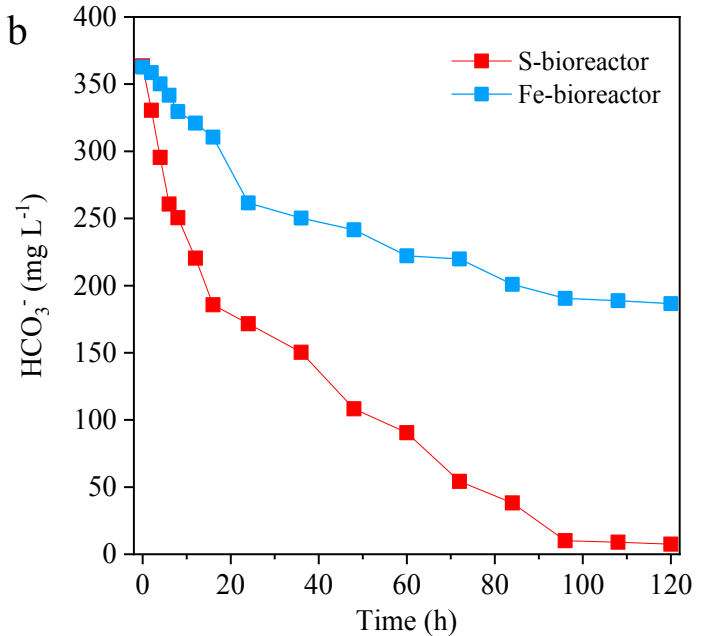

106 Figure S6. Change of $\mathrm{pH}(\mathrm{a})$ and $\mathrm{HCO}_{3}{ }^{-}$concentration (b) in one cycle (120 hours) of

107 the S- and Fe-bioreactors. The red color represents the S-bioreactor and the blue color 108 represents the Fe-bioreactor. 

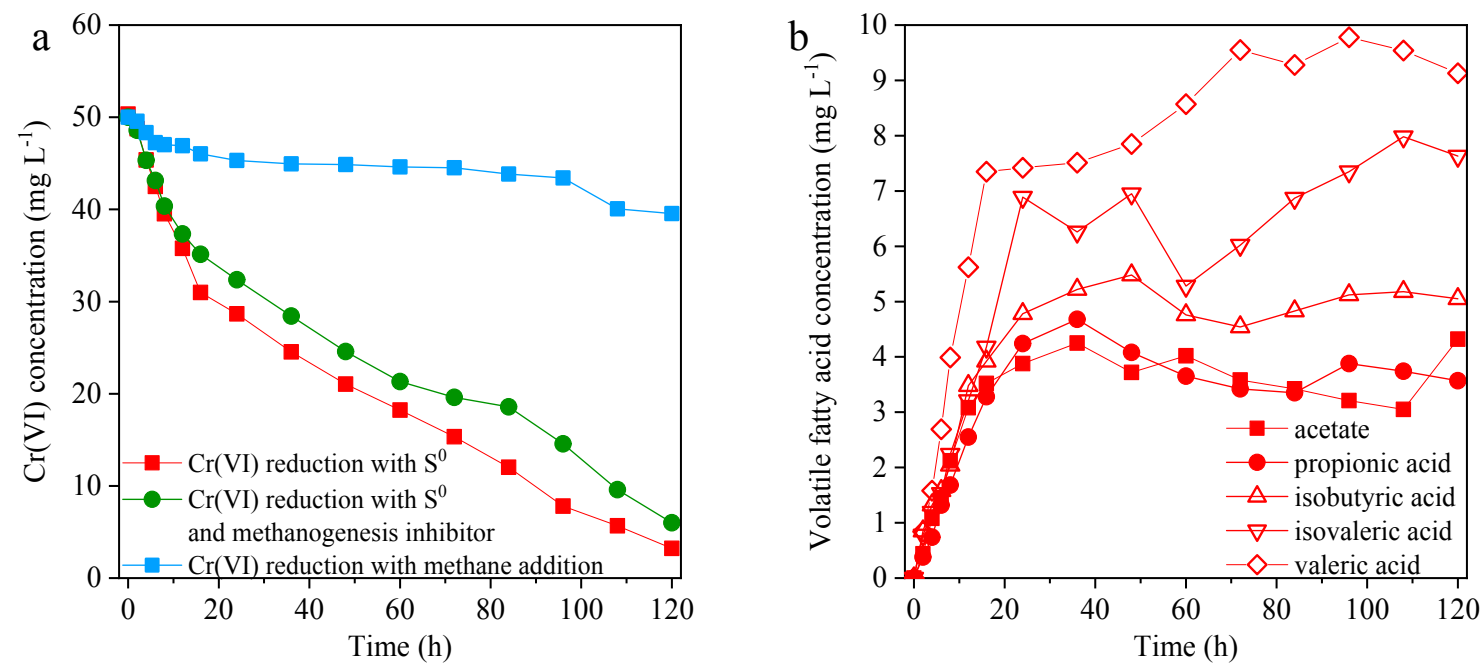

111 Figure S7. Change of $\mathrm{Cr}(\mathrm{VI})$ concentration and volatile fatty acid (VFA) concentration

112 in the $\mathrm{S}$ bioreactors. (a) Comparison of $\mathrm{Cr}(\mathrm{VI})$ concentration in three bioreactors

113 amended with $\mathrm{S}^{0}, \mathrm{~S}^{0}$ and methanogenesis inhibitor, and methane, respectively. (b) VFA

114 concentrations in the bioreactor with $\mathrm{S}^{0}$ and methanogenesis inhibitor. 
Text 1. Chains of geochemical reactions and Gibbs free energy calculations in the two bioreactors

\section{S-bioreactor:}

Pathway \#1 : Methane oxidation coupled with chromium reduction

$\mathrm{H}^{+}(0)+\mathrm{HCO}_{3}{ }^{-}(-586.85)=\mathrm{CO}_{2}(-394.359)+\mathrm{H}_{2} \mathrm{O}(-237.178) \Delta \mathrm{G}=-44.7 \mathrm{~kJ} / \mathrm{mol}$

$2 \mathrm{CO}_{2}(-394.359)+4 \mathrm{H}_{2}(0)=\mathrm{CH}_{3} \mathrm{COOH}(-369.41)+2 \mathrm{H}_{2} \mathrm{O}(-237.178) \Delta \mathrm{G}=-55.0 \mathrm{~kJ} / \mathrm{mol}$

$4 \mathrm{H}_{2}(0)+\mathrm{CO}_{2}(-394.359)=\mathrm{CH}_{4}(-50.79)+2 \mathrm{H}_{2} \mathrm{O}(-237.178) \Delta \mathrm{G}=-130.8 \mathrm{~kJ} / \mathrm{mol}$

$\mathrm{CH}_{3} \mathrm{COOH}(-369.41)=\mathrm{CH}_{4}(-50.79)+\mathrm{CO}_{2}(-394.359) \Delta \mathrm{G}=-75.7 \mathrm{~kJ} / \mathrm{mol}$

$\mathrm{CrO}_{4}{ }^{2-}(-727.8)+0.375 \mathrm{CH}_{4}(-50.79)+4.625 \mathrm{H}^{+}(0)=\mathrm{Cr}^{3+}(-198.27)+2.875 \mathrm{H}_{2} \mathrm{O}(-237.178)+0.375$

$\mathrm{HCO}_{3}{ }^{-}(-586.85) \triangle \mathrm{G}=-353.4 \mathrm{~kJ} / \mathrm{mol}$

$\mathrm{CrO}_{4}{ }^{2-}(-727.8)+1.625 \mathrm{H}^{+}(0)+0.125 \mathrm{H}_{2} \mathrm{O}(-237.178)+0.375 \mathrm{CH}_{4}(-50.79)=\mathrm{Cr}(\mathrm{OH})_{3}(-846.94)+$

$0.375 \mathrm{HCO}_{3}^{-}(-586.85) \Delta \mathrm{G}=-290.5 \mathrm{~kJ} / \mathrm{mol}$

Pathway \#2 : VFA oxidation coupled with chromium reduction

$\mathrm{CrO}_{4}{ }^{2-}(-727.8)+0.375 \mathrm{CH}_{3} \mathrm{COO}^{-}(-369.31)+4.625 \mathrm{H}^{+}(0)=\mathrm{Cr}^{3+}(-198.27)+2.5 \mathrm{H}_{2} \mathrm{O}(-237.178)+$

$0.75 \mathrm{HCO}_{3}^{-}(-586.85) \triangle \mathrm{G}=-365.1 \mathrm{~kJ} / \mathrm{mol}$

$\mathrm{CrO}_{4}{ }^{2-}(-727.8)+1.625 \mathrm{H}^{+}(0)+0.5 \mathrm{H}_{2} \mathrm{O}(-237.178)+0.375 \mathrm{CH}_{3} \mathrm{COO}^{-}(-369.31)=\mathrm{Cr}(\mathrm{OH})_{3}(-846.94)$

$+0.75 \mathrm{HCO}_{3}^{-}(-586.85){ }^{-} \mathrm{G}=-302.2 \mathrm{~kJ} / \mathrm{mol}$

Pathway \#3 : Sulfur oxidation coupled with chromium reduction

$2 \mathrm{CrO}_{4}{ }^{2-}(-727.8)+17 \mathrm{~S}^{0}(0)+24 \mathrm{HCO}_{3}{ }^{-}(-586.85)+12 \mathrm{H}_{2} \mathrm{O}(-237.178)=12 \mathrm{CH}_{3} \mathrm{COOH}(-369.41)+$

$2 \mathrm{Cr}^{3+}(-198.27)+17 \mathrm{SO}_{4}{ }^{2-}(-744.63) \Delta \mathrm{G}=898.0 \mathrm{~kJ} / \mathrm{mol}$

Pathway \#4 : Sulfide oxidation coupled with chromium reduction

$\mathrm{CrO}_{4}^{2-}(-727.8)+0.375 \mathrm{HS}^{-}(12.05)+4.625 \mathrm{H}^{+}(0)=\mathrm{Cr}^{3+}(-198.27)+2.5 \mathrm{H}_{2} \mathrm{O}(-237.178)+0.375$

$\mathrm{SO}_{4}{ }^{2-}(-744.63) \triangle{ }^{\circ}=-347.2 \mathrm{~kJ} / \mathrm{mol}$

$\mathrm{CrO}_{4}{ }^{2-}(-727.8)+1.625 \mathrm{H}^{+}(0)+0.5 \mathrm{H}_{2} \mathrm{O}(-237.178)+0.375 \mathrm{HS}^{-}(12.05)=\mathrm{Cr}(\mathrm{OH})_{3}(-846.94)+0.375$ 
144

145

146

147

148

149

150

151

152

153

154

155

156

157

158

159

160

161

162

163

164

165

166

167

168

169

170

$\mathrm{SO}_{4}{ }^{2-}(-744.63) \triangle \mathrm{G}=-284.3 \mathrm{~kJ} / \mathrm{mol}$

\section{Fe-bioreactor:}

Pathway \#1: Methane oxidation coupled with chromium reduction

$\mathrm{H}^{+}(0)+\mathrm{HCO}_{3}{ }^{-}(-586.85)=\mathrm{CO}_{2}(-394.359)+\mathrm{H}_{2} \mathrm{O}(-237.178) \Delta \mathrm{G}=-44.7 \mathrm{~kJ} / \mathrm{mol}$

$2 \mathrm{CO}_{2}(-394.359)+4 \mathrm{H}_{2}(0)=\mathrm{CH}_{3} \mathrm{COOH}(-369.41)+2 \mathrm{H}_{2} \mathrm{O}(-237.178) \Delta \mathrm{G}=-55.0 \mathrm{~kJ} / \mathrm{mol}$

$4 \mathrm{H}_{2}(0)+\mathrm{CO}_{2}(-394.359)=\mathrm{CH}_{4}(-50.79)+2 \mathrm{H}_{2} \mathrm{O}(-237.178) \Delta \mathrm{G}=-130.8 \mathrm{~kJ} / \mathrm{mol}$

$\mathrm{CH}_{3} \mathrm{COOH}(-369.41)=\mathrm{CH}_{4}(-50.79)+\mathrm{CO}_{2}(-394.359) \Delta \mathrm{G}=-75.7 \mathrm{~kJ} / \mathrm{mol}$

$\mathrm{CrO}_{4}{ }^{2-}(-727.8)+0.375 \mathrm{CH}_{4}(-50.79)+4.625 \mathrm{H}^{+}(0)=\mathrm{Cr}^{3+}(-198.27)+2.875 \mathrm{H}_{2} \mathrm{O}(-237.178)+0.375$

$\mathrm{HCO}_{3}{ }^{-}(-586.85) \triangle \mathrm{G}=-353.4 \mathrm{~kJ} / \mathrm{mol}$

$\mathrm{CrO}_{4}{ }^{2-}(-727.8)+1.625 \mathrm{H}^{+}(0)+0.125 \mathrm{H}_{2} \mathrm{O}(-237.178)+0.375 \mathrm{CH}_{4}(-50.79)=\mathrm{Cr}(\mathrm{OH})_{3}(-846.94)+$

$0.375 \mathrm{HCO}_{3}^{-}(-586.85) \triangle^{\mathrm{G}}=-290.5 \mathrm{~kJ} / \mathrm{mol}$

Pathway \#2 : VFA oxidation coupled with chromium reduction

$\mathrm{CrO}_{4}{ }^{2-}(-727.8)+0.375 \mathrm{CH}_{3} \mathrm{COO}^{-}(-369.31)+4.625 \mathrm{H}^{+}(0)=\mathrm{Cr}^{3+}(-198.27)+2.5 \mathrm{H}_{2} \mathrm{O}(-237.178)+$

$0.75 \mathrm{HCO}_{3}{ }^{-}(-586.85) \triangle \mathrm{G}=-365.1 \mathrm{~kJ} / \mathrm{mol}$

$\mathrm{CrO}_{4}{ }^{2-}(-727.8)+1.625 \mathrm{H}^{+}(0)+0.5 \mathrm{H}_{2} \mathrm{O}(-237.178)+0.375 \mathrm{CH}_{3} \mathrm{COO}^{-}(-369.31)=\mathrm{Cr}(\mathrm{OH})_{3}(-846.94)$

$+0.75 \mathrm{HCO}_{3}^{-}(-586.85) \Delta \mathrm{G}=-302.2 \mathrm{~kJ} / \mathrm{mol}$

Pathway \#3: $\mathrm{H}_{2}$ oxidation coupled with chromium reduction

$0.33 \mathrm{CrO}_{4}^{2-}+1.67 \mathrm{H}^{+}+0.5 \mathrm{H}_{2}=0.33 \mathrm{Cr}^{3+}+1.33 \mathrm{H}_{2} \mathrm{O} \quad \Delta \mathrm{G}=-45.02 \mathrm{~kJ} / \mathrm{mol}$

$2 \mathrm{CrO}_{4}{ }^{2-}(-727.8)+3 \mathrm{H}_{2}(0)+10 \mathrm{H}^{+}(0)=2 \mathrm{Cr}^{3+}(-198.27)+8 \mathrm{H}_{2} \mathrm{O}(-237.178) \Delta \mathrm{G}=-838.36 \mathrm{~kJ} / \mathrm{mol}$

Pathway \#4: $\mathrm{Fe}^{2+}$ oxidation coupled with chromium reduction

$\mathrm{CrO}_{4}{ }^{2-}(-727.8)+3 \mathrm{Fe}^{2+}(-78.87)+8 \mathrm{H}^{+}(0)=\mathrm{Cr}^{3+}(-198.27)+3 \mathrm{Fe}^{3+}(-4.6)+4 \mathrm{H}_{2} \mathrm{O}(-237.178) \Delta \mathrm{G}=$ $-196.37 \mathrm{~kJ} / \mathrm{mol}$ 